\title{
Development of a Solar Copra Dryer Incorporated with Evacuated Tubes
}

\author{
V.Sai Krishna* and George Mathew \\ Department of Food and Agricultural Process Engineering, Kelappaji College of Agricultural \\ Engineering and Technology, Kerala Agricultural University, Kerala, India \\ *Corresponding author
}

\section{A B S T R A C T}

\begin{tabular}{|l|}
\hline Ke y w o r d s \\
$\begin{array}{l}\text { Solar Dryer, Copra, } \\
\text { Development, Evacuated } \\
\text { tube collector, forced } \\
\text { convection, indirect } \\
\text { drying }\end{array}$ \\
\hline Article Info \\
\hline $\begin{array}{l}\text { Accepted: } \\
\text { 20 May } 2018 \\
\text { Available Online: } \\
\text { 10 June } 2018\end{array}$ \\
\hline
\end{tabular}

Kerala is the region with high humidity and comparatively low solar radiation, there is much scope of uneven and uncontrolled drying of copra. Hence, an attempt was made to develop a sophisticated and advanced forced convection solar dryer. Evacuated tube collector (ETC) was used to generate hot air and used to dry coconuts. It consists of three units: evacuated tube collector, blower and drying chamber. Coconuts (Cocos nucifera) were dried at full load condition in order to evaluate the performance of the developed solar dryer. The drying chamber temperature observed was of $70^{\circ} \mathrm{C}$ for safe drying of coconuts. The dryer has a mean drying capacity of $20 \mathrm{~kg}$ per batch, each batch took $28 \mathrm{~h}$ to complete drying the coconuts form initial moisture content $52.5 \%$ to final moisture content of $7 \%$. The collector efficiency of the solar evacuated tube collector was $44 \%$, total number of tubes used were 30 . Hence, better quality copra was produced in minimum time of $28 \mathrm{~h}$.

\section{Introduction}

Fresh coconut contains moisture content of about 52 per cent (wb) which has to be reduced down to 6-7 per cent (wb) by drying in order to concentrate the oil content (Sachidananda et al., 2014). On an average, 57 coconuts are essential to produce one $\mathrm{kg}$ of copra, although this depends on the grade of product. Copra is one of the major traditional products processed from coconuts.

The objective of making copra is to reduce the moisture content of coconut kernel to a safe storage level and thereby prevent microbiological attack and spoilage. The utilization of solar energy as a reliable energy source to dry foods in India has a great potential.

Sun shines in India over an average of 30003200 h.year $^{-1}\left(11\right.$ h.day $\left.^{-1}\right)$ delivering about $2000 \mathrm{kWh} . \mathrm{m}^{-2}$ year $^{-1}\left(8 \mathrm{kWh} . \mathrm{m}^{-2}\right.$ day $\left.^{-1}\right)$ of solar radiation on horizontal surface (Kulanthaisami et al., 2009).

Open sun drying and kiln drying is the most commonly used method for drying coconut kernels in most of the developing countries. Drying under hostile climate conditions usually leads to severe losses in the quantity and quality of the product. They produce poor quality copra and also take time to attain the equilibrium moisture content. 
In kiln drying, smoke has direct contact with the coconut and result in poor quality copra due to smoke deposits which alters polycyclic aromatic hydrocarbons in the copra. Sun drying takes 7 to 8 days and if the weather is rainy the copra obtained will be contaminated with fungi which produce a grey rancid product. Moreover there can be produce of low quality copra from deposits of dirt and dust. Also, microorganisms can cause rancidity, increase the acid content and reduce the amount of oil extracted from the product resulting in low quality coconut oil. The oil extracted from poor-quality copra also requires additional refinement to meet international standards (Shanmugam and Natarajan, 2006).

The quality of copra and its cake is influenced by the method of drying the coconut kernel. Improperly dried copra gives rise to certain moulds, the most harmful of which is the yellow green mould called Aspergillus flavus and other aflatoxin related moulds. Aflatoxin is harmful both for man and animals. Improper processing results in low oil yield hence, proper post-harvest practices, as well as proper drying and storage can increase the oil yield to about 20 per cent. Proper drying of coconut results in copra with lower moisture content and lower incidence of aflatoxins.

On the other hand, mechanical drying is an energy consuming operation. Solar dryers are now being increasingly used since they are better and more energy efficient option.

The benefits from the installation and operation of solar energy systems can be divided into three categories: energy saving, generation of job opportunities and a decrease in environmental pollution. Therefore, using solar energy can be considerably reduced energy costs. The efficiency of a solar dryer depends on its type and model as well as on the rate of heat loss during operation.

\section{Materials and Methods}

Solar Evacuated Tube Collector was developed at KCAET, Tavanur, Kerala, India located at installed at roof top of college guest house at $10^{\circ} 51^{\prime} 13.75^{\prime \prime}$ north latitude, $75^{\circ} 59^{\prime} 14.08^{\prime \prime}$ east longitude and altitude of 27 $\mathrm{m}$ above mean sea level, inside the campus. The dryer is made up of three sections, the energy source (Solar ETC setup), blower and the drying chamber sections.

The solar dryer is located behind the dryer facing the south at declination angle of $-2.52^{\circ}$, which is used to collect maximum solar radiation available in the ambient. The suction fan is connected to solar collector which sucks the air and blows into the drying chamber. A $110 \mathrm{~W}$ fan is used, which is operated at a velocity of $0.8 \mathrm{~m} / \mathrm{s}$ which helps in maintaining the temperature within the drying chamber (75 $\left.{ }^{\circ} \mathrm{C}\right)$.

The chamber is fabricated from galvanized steel of $2 \mathrm{~mm}$ thickness and the $12.5 \mathrm{~mm}$ glass wool slab (supported with cardboard) was used as insulating medium to control heat loss by conduction. The drying chamber has 2 trays with single door. The trays are perforated to effectively allow the airflow within the chamber. The drying chamber consists of $75 \mathrm{x}$ $75 \times 50 \mathrm{~cm}$ length, breadth and height, respectively. The developed forced convection solar dryer is illustrated in Figure 1 and Figure 2. The fabrication was then carried out based on the design calculation below.

\section{Results and Discussion}

\section{Design Calculations}

The design of solar dryer was done by taking into consideration the following parameters: Amount of moisture to be removed, quantity of air required, volume of air required, blower fan efficiency, quantity of heat required, 
collector area of evacuated glass tubes, heat transfer rate, selection of drying chamber volume, thickness of insulation, number of evacuated tubes, actual heat used to effect drying, rate of mass transfer, collector efficiency.

The average ambient temperature and Relative Humidity (RH) were measured as $30{ }^{\circ} \mathrm{C}$ and $70 \%$, respectively. And, the drying chamber temperature was assumed to be $70{ }^{\circ} \mathrm{C}$ respectively, tray size of $750 \mathrm{~mm} \times 750 \mathrm{~mm}$ with capacity of $20 \mathrm{~kg}$ per batch.

\section{Amount of moisture to be removed}

The moisture content of the fresh coconuts which was collected from KCAET farm, was determined by using hot air oven method, where the initial moisture content $\left(\mathrm{Q}_{1}\right)$ and final moisture content $\left(\mathrm{Q}_{2}\right)$ were 55 and seven per cent, respectively. In order to avoid poor quality of copra the moisture content of the product must be reduced to 35 per cent within $12 \mathrm{~h}$ of drying and in next $12 \mathrm{~h}$ the moisture had to reduce from 35 per cent to 20 per cent. And remaining time is taken to reach its final moisture content of seven per cent. So the amount of moisture to be removed from 55 to 35 per cent was calculated as $6.15 \mathrm{~kg}$. The amount of moisture removed from 35 to 20 per cent was $2.59 \mathrm{~kg}$ and from 20 to 7 per cent moisture content was $1.57 \mathrm{~kg}$. (Mohanraj and Chandrasekar, 2008)

$M_{R}=M^{\left(\frac{Q_{1}-Q_{2}}{1-Q_{2}}\right)}$

Hence, the total amount of moisture to be removed $\left(\mathrm{M}_{\mathrm{R}}\right)$ for drying $20 \mathrm{~kg}$ coconut was calculated as $10.32 \mathrm{~kg}$.

\section{Quantity of air required (Qa)}

The quantity of air required to effect drying in $\mathrm{kg}$ was calculated using formula given below (Ajisegiri et al., 2006):
$\mathrm{Q}_{\mathrm{a}}=\left(\frac{\mathrm{M}_{\mathrm{R}}}{\mathrm{H}_{\mathrm{r} 2}-\mathrm{H}_{\mathrm{r} 1}}\right)$

The quantity of air required for effective drying $\left(\mathrm{Q}_{\mathrm{a}}\right)$ depends on the initial humidity ratios $\left(\mathrm{H}_{\mathrm{r} 1}\right)$, final humidity ratios $\left(\mathrm{H}_{\mathrm{r} 2}\right)$ and moisture to be removed $\left(\mathrm{M}_{\mathrm{R}}\right)$ which was observed as $0.0215 \mathrm{~kg}$ water vapour. $\mathrm{kg}^{-1}$ dry air, $0.041 \mathrm{~kg}$ water vapour. $\mathrm{kg}^{-1}$ dry air and $10.32 \mathrm{~kg}$, respectively.

The quantity of air required for effective drying was calculated as $529.38 \mathrm{~kg}$.

\section{Volume of air required}

The volume $\left(\mathrm{m}^{3}\right)$ of air required to effect drying was given as (Ajisegiri et al., 2006):

$\mathrm{V}_{\mathrm{a}}=\left(\frac{\mathrm{Q}_{\mathrm{a}}}{\mathrm{p}_{\mathrm{a}}}\right)$

Where, $\rho_{\mathrm{a}}=$ density of air $\left(\mathrm{kg} \cdot \mathrm{m}^{-3}\right)$, The volume of air required for effective drying $\left(V_{A}\right)$ is calculated as $474.78 \mathrm{~m}^{3}$, where the density $\left(\rho_{\mathrm{a}}\right)$ of air at $0{ }^{\circ} \mathrm{C}$ was $1.115 \mathrm{~kg} \cdot \mathrm{m}^{-3}$ based on properties of common fluid.

\section{Blower fan efficiency}

The blower serves the purpose of transferring heated air from the heat exchanger to the dryer cabinet.

The selection was based on the characteristics of centrifugal fan performance given in the equation below (Akpan et al., 2016):

Fan efficiency $=\frac{P_{\text {out }}}{P_{\text {in }}}$

$\mathrm{P}_{\text {in }}=\mathrm{V} \times \mathrm{I}$ and, $\mathrm{P}_{\text {out }}=\mathrm{A}_{\mathrm{f}} \times \mathrm{A}_{\mathrm{p}}$

Therefore, the input and output power are calculated as $130 \mathrm{~W}$ and $40.78 \mathrm{~W}$. By using this, the fan efficiency is calculated as 46.34 per cent. 


\section{Quantity of heat required to effect drying}

The quantity of heat required for effective drying is mainly dependent on two parameters, amount of moisture to be removed and rate at which it has to be removed. The dryer capacity per batch (M) was $20 \mathrm{~kg}$, Specific heat of the product $\left(\mathrm{C}_{\mathrm{t}}\right)$ was 1.988 kJ.kg ${ }^{-1} \mathrm{~K}^{-1}$. Temperatures gradient $(\Delta \mathrm{T})$ between ambient temperature $\left(30{ }^{\circ} \mathrm{C}\right)$ and inside dryer chamber temperature $\left(70^{\circ} \mathrm{C}\right)$ was $40{ }^{\circ} \mathrm{C}$. Latent heat of vaporization $\left(\mathrm{H}_{\mathrm{L}}\right)$ is $2260 \mathrm{~kJ} \cdot \mathrm{kg}^{-1}$ and amount of moisture to be removed $\left(\mathrm{M}_{\mathrm{R}}\right)$ was $10.32 \mathrm{~kg}$. The effective heat efficiency is calculated as 69.7 per cent by measuring the ambient temperature $\left(\mathrm{T}_{1}\right)$ as $30{ }^{\circ} \mathrm{C}$, dryer outlet temperature $\left(\mathrm{T}_{2}\right)$ as $70{ }^{\circ} \mathrm{C}$, dryer outlet wet bulb temperature $\left(\mathrm{T}_{\mathrm{w} 2}\right)$ as 27 ${ }^{\circ} \mathrm{C}$. The quantity of heat required $\left(\mathrm{H}_{\mathrm{r}}\right)$ for drying in kJ is given by (Akpan et al., 2016):

$\eta=\frac{\mathrm{T}_{2}-\mathrm{T}_{3}}{\mathrm{~T}_{2}-\mathrm{T}_{\mathrm{w} 2}}$

Therefore, the total Quantity of heat required was calculated as $35057.09 \mathrm{~kJ}$. By considering external heat losses of 10 percent, the final heat requirement was calculated as 38562.8 $\mathrm{kJ}$.

\section{Collector area of evacuated glass tubes}

The length $\left(\mathrm{L}_{\mathrm{g}}\right)$ of the tube was $1.5 \mathrm{~m}$ and the diameter is $0.047 \mathrm{~m}$. The total number of tubes was 30. The Collector area (A) is the area of solar evacuated tubes which is projected towards the sun direction, it can be calculated as,

Collector area $(\mathrm{A})=\left[\mathrm{L}_{\mathrm{g}} \times \mathrm{C} / 2\right] \times n$

The collector area is calculated based on the amount of energy required to perform the drying operation. The total solar energy available at KCAET, Tavanur in the month of March was $21847.71 \mathrm{~kJ} . \mathrm{m}^{-2}$ day $^{-1}$. To dry the coconuts in $30 \mathrm{hrs}$, the amount of heat required was calculated as $35057.09 \mathrm{~kJ}$. Hence, in one hour $1168.56 \mathrm{~kJ}$ of energy is required. Available solar energy per hour is calculated as $910.32 \mathrm{~kJ} \cdot \mathrm{h}^{-1}$.

Therefore, the area of collector surface required calculated as following,

Required collector area $=\frac{1168.56 \times 1}{910.22 \times 0.40}=3.20 \mathrm{~m}^{2}$

\section{Heat transfer rate $\left(Q_{h t}\right)$}

In order to compute heat transfer rate the convective heat transfer coefficient of ambient was calculated. The Reynolds number was calculated to be 35356.51 which was less than $3 \times 10^{5}$, therefore the flow was laminar.

And, Nusselt number was calculated as 111.43. By using thermal conductivity of air at $40{ }^{\circ} \mathrm{C}$, i.e., $0.0271 \mathrm{~W} \cdot \mathrm{m}^{-1} \mathrm{~K}^{-1}$ the convective heat transfer coefficient is determined as 4.02 $\mathrm{W} \cdot \mathrm{m}^{-2} \mathrm{~K}^{-1}$. The heat transfer rate $\left(\mathrm{Q}_{\mathrm{ht}}\right)$ can be determined (Comwel, 1978) as:

$\mathrm{Q}_{\mathrm{ht}}=\mathrm{hAT}_{\mathrm{B}}$

$h=\frac{\left(\bar{N}_{n \Psi} K_{f}\right)}{L}$

$\mathrm{R}_{\mathrm{e}}=\overline{\mathrm{VXL}}_{\mathrm{Y}}^{\mathrm{V}}$ and, $\overline{\mathrm{N}}_{\mathrm{mI}}=0.664{ }_{\mathrm{Re}}^{0.5} N_{P Y}^{0.93 \mathrm{~s}}$

Where, $\mathrm{N}_{\mathrm{pr}}=0.711,{ }^{\gamma}=16.97 \times 10^{-6} \mathrm{~m}^{2} \cdot \mathrm{s}^{-1}, K_{f}=$ $0.0271 \mathrm{~W} \cdot \mathrm{m}^{-1} \mathrm{~K}^{-1}, \mathrm{~h}=$ heat transfer coefficient, $\mathrm{A}=$ surface area of the heating medium $\left(\mathrm{m}^{2}\right)$, $\mathrm{T}_{\mathrm{B}}=$ temperature of hot air in the blower $\left({ }^{\circ} \mathrm{C}\right)$, $\mathrm{v}=$ ambient air velocity $\left(\mathrm{m} \cdot \mathrm{s}^{-1}\right), \quad \mathrm{L}=$ characteristic linear dimension $(\mathrm{m}), \quad \gamma=$ kinematic viscosity $\left(\mathrm{m}^{2} \cdot \mathrm{s}^{-1}\right)$. Hence, the heat transfer rate is calculated as $534.65 \mathrm{~W}$.

\section{Selection of drying Chamber volume}

In order to accommodate $20 \mathrm{~kg}$ of coconuts which counts 50 in number (approximately), there must be sufficient area for placing the coconuts. 
Fig.1 Fabricated solar evacuated tube air dryer

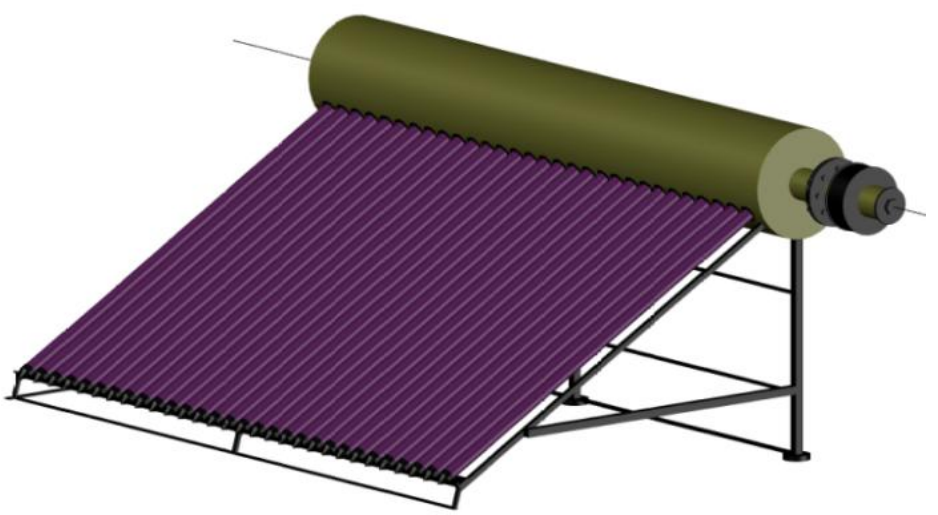

Fig.2 Front view solar evacuated tube air dryer

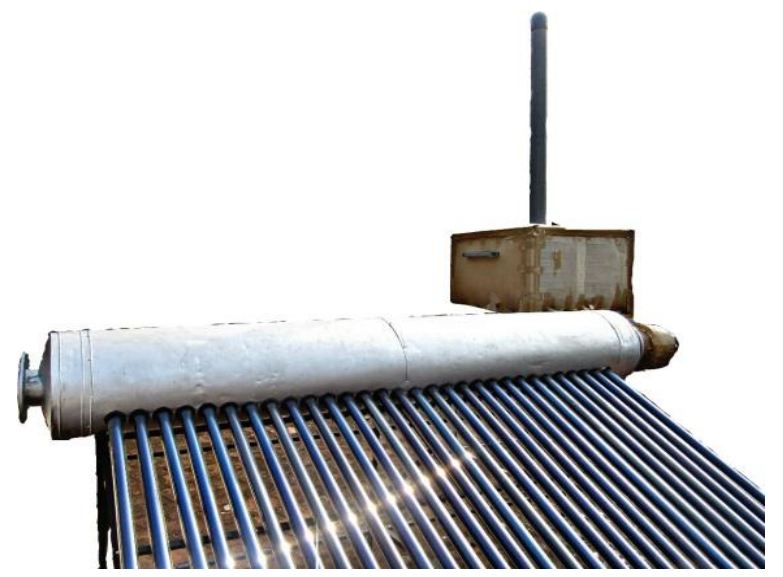

Fig.3 Full load drying chamber

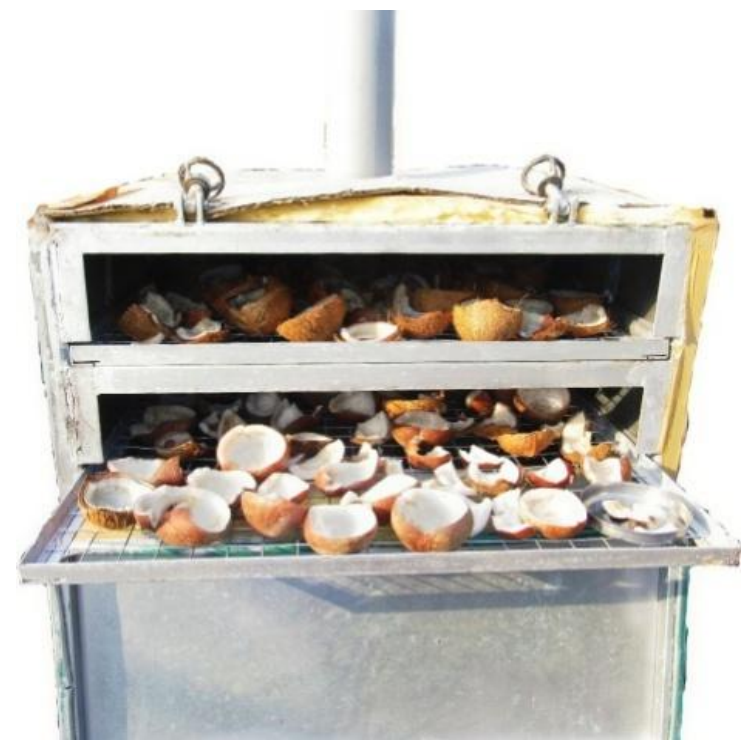


Fig.4 Side view of solar copra dryer

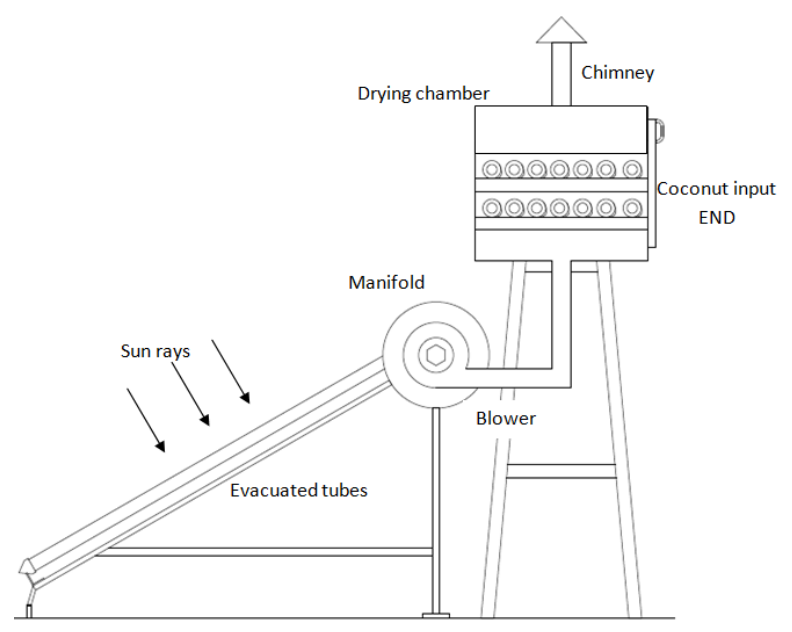

By considering the ergonomic aspects and necessary spacing between the trays, the height of the chamber was selected to be $0.5 \mathrm{~m}$. The height of one split coconut was $5 \mathrm{~cm}$ and maximum diameter was $10 \mathrm{~cm}$.

Area of tray $\left(\mathrm{A}_{\mathrm{T}}\right)=\mathrm{L}^{2}$

Length of tray $(\mathrm{L})=n \times \mathrm{D}_{\mathrm{c}}$

Volume of dryer chamber $\left(V_{c}\right)=A_{T} x h$

By using this data, 7-8 coconuts can be arranged in $75 \mathrm{~cm}$ length. If the diameter of the coconuts is smaller than $10 \mathrm{~cm}$ then the dryer can accommodate 8-9 coconuts in a row which gives 64 split coconuts per tray. The opening was provided on one side with air tight locking system in order to minimize heat loss and escape of hot air from the chamber. Hence two trays having an area of $0.75 \times 0.75$ $\mathrm{m}^{2}$ were selected.

\section{Thickness of insulation}

Glass wool material is selected for insulating the drying chamber to avoid heat losses. The critical thickness of the glass wool is calculated by using the following equation (Geankoplis, 2011):

$\mathrm{R}_{\mathrm{c}}=\frac{k}{h_{0}}$
The thermal conductivity of glass wool slab was $0.043 \mathrm{~W} \cdot \mathrm{m}^{-1} \mathrm{~K}^{-1}$. (Tittarelli et al., 2013). The critical thickness was calculated as 10 $\mathrm{mm}$. Hence, $12.5 \mathrm{~mm}$ thick glass wool is provided as insulating material supported by paper card board.

\section{Number of evacuated tubes}

The determination of number of tubes depends on the size of each tube available commercially. It is given by the following equation:

Number of tubes $=\left(\frac{\text { Collector area required }}{\text { projected area of standard tuba }}\right)$

The collector area is calculated as $3.32 \mathrm{~m}^{2}$ and the projected area of solar evacuated tubes is the number of tubes is calculated as 30 .

\section{Actual heat used to effect drying $\left(\mathrm{H}_{\mathrm{D}}\right)$}

The quantity of heat used in effecting drying $\mathrm{H}_{\mathrm{D}}$ in $\mathrm{kJ}$ can be determined as in equation below (Akpan et al., 2016):

$\mathrm{H}_{\mathrm{D}}=\mathrm{C}_{\mathrm{a}} \mathrm{T}_{\mathrm{c}} \mathrm{M}_{\mathrm{r}}$

The amount of moisture to be removed from the sample is already estimated as $10.323 \mathrm{~kg}$, 
specific heat capacity of air is $1.005 \mathrm{~kJ} . \mathrm{kg}^{-1} \mathrm{~K}^{-}$ 1 and the temperature difference is $40{ }^{\circ} \mathrm{C}$. Hence, the actual heat used to effect drying is calculated as $3247.25 \mathrm{~kJ}$.

\section{Rate of mass transfer}

The mass transfer rate $Q_{m t r}$ in $\mathrm{kg}$ is determined by using the following equation (Akpan et al., 2016):

$\mathrm{Q}_{\mathrm{mtr}}=\mathrm{M}_{\mathrm{c}} \mathrm{A}_{\mathrm{t}}\left(\mathrm{H}_{\mathrm{r} 1}-\mathrm{H}_{\mathrm{r} 2}\right) \mathrm{q}_{2}$

The mass transfer coefficient of a free water surface was $0.083 \mathrm{~kg} \cdot \mathrm{m}^{-2} \mathrm{~s}^{-1}$, the total surface area of the two trays was $1.125 \mathrm{~m}^{2}$, air flow rate is $0.8 \mathrm{~m} . \mathrm{s}^{-1}$ and the difference between humidity ratios is $0.0195 \mathrm{~kg} \cdot \mathrm{kg}^{-1}$ dry air. Therefore, the rate of mass transfer is calculated as $1.4 \times 10^{-3} \mathrm{~kg}$.

\section{Thermal Efficiency of the Dryer}

The collector efficiency of the dryer, $\eta$ is calculated using the following equation (Sopian et al., 2009):

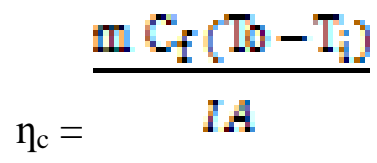

The thermal efficiency of the dryer was determined by using mass flow rate of air (m) which was $7.712 \times 10^{-3} \mathrm{~kg} . \mathrm{s}^{-1}$, air specific heat $\left(\mathrm{C}_{\mathrm{p}}\right)$ was $1.005 \mathrm{~kJ} . \mathrm{kg}^{-1} \mathrm{~K}^{-1}$, temperature gradient is $45{ }^{\circ} \mathrm{C}$, solar insolation (I) was 236.7 W.m ${ }^{-2}$ and collector area (A) was calculated as $3.32 \mathrm{~m}^{2}$. Therefore, the collector efficiency was calculated as 44.36 percent.

\section{Description of the Dryer}

The dryer is cubical in shape with external dimensions of $750 \mathrm{~mm} \times 750 \mathrm{~mm} \times 500 \mathrm{~mm}$. The components of the dryer include: the drying chamber, the tray, the insulation, the chimney, the solar evacuated tube collector, the blower fan and supporting stand.

\section{The Evacuated tube collector}

The test section of the evacuated tube used in this system is shown in figure 4.1. Each evacuated tube consists of two glass tubes made from extremely strong borosilicate glass. The outer tube was transparent borosilicate glass allowing light rays to pass through with minimal reflection. The inner tube was coated with a special selective coating (Aluminium/ Nickle) which gives excellent solar radiation absorption and minimal reflection properties. All the evacuated tubes are attached to cylindrical manifold incorporated with two concentric cylinders. Since both the cylinders run at two different temperatures, they are separated by glass wool insulation in order to minimize heat transfer losses.

\section{The Air blower}

An Air blower was connected to the evacuated tube collector at right side of the header which forces the air to the drying chamber. The blower was connected to drying chamber by galvanized metal tube. The velocity of the blower was controlled by using a regulator.

\section{The Drying chamber}

The chamber was designed using galvanized steel metal sheets. The chamber consists of 2 lids one at top and other at bottom. Top lid was provided with an outlet made of PVC pipe for ducting the exhaust air. A 24 gauge galvanized iron sheet was used to fabricate the chamber. Two perforated metal trays of 10-mesh was fitted inside the chamber for placing the fresh coconuts for drying and for the passage of air through the coconuts. The drying chamber and the solar evacuated tube 
collector were connected by metal duct. All the sides were welded in order to prevent air leakages. Blower was placed in between the dryer and ETC in order to force the hot air into the drying chamber. A door was provided at one side of the chamber for handling the product to be dried.

\section{The Insulator}

It is necessary to install proper insulation to control heat losses, to increase the drying efficiency and to maintain uniform drying. Glass wool slab was selected as the insulating material whose critical thickness was $10 \mathrm{~mm}$. The thermal conductivity of the glass wool is $0.043 \mathrm{~W} . \mathrm{m}^{-1} \mathrm{~K}^{-1}$. The insulation was provided on the outer side of the drying chamber.

\section{Supporting stand}

A supporting stand fabricated for placing the header and evacuated tubes in fixed positions. The collector was placed at angle of 30'54" facing south by means of the fixed stand.

\section{Working Drawings}

The solar drying was conducted at Kelappaji College of Engineering and Technology, Tavanur. This place is situated at $10^{\circ} 51^{\prime} 8.88^{\prime \prime}$ north latitude and 75 59'8.61" east longitude. Solar evacuated tube collector was installed at roof top of college guest house at $10^{\circ} 51 ' 13.75^{\prime \prime}$ north latitude, $75^{\circ} 59^{\prime} 14.08^{\prime \prime}$ east longitude and altitude of $27 \mathrm{~m}$ above mean sea level, inside the campus.

The experiments were carried out from $2^{\text {nd }}$ March to $29^{\text {th }}$ May 2017. The capacity of dryer was $20 \mathrm{~kg}$ which can accommodate 50 coconuts. The coconuts were procured from KCAET Farm. The performance of the dryer was evaluated by drying the coconuts under full load condition. The dryer can accommodate $20 \mathrm{~kg}$ of coconut per batch.
There are two trays; each tray carries $10 \mathrm{~kg}$ coconuts each. The dryer was operated for $8 \mathrm{~h}$ in a day and temperature was maintained in the range of 65 to $75{ }^{\circ} \mathrm{C}$. The blower was operated at a velocity of $0.8 \mathrm{~m} / \mathrm{s}$. The hot air coming out of the solar evacuated tube collector was forced into the drying chamber from the bottom and leaves the chamber through the top of the chamber.

A forced convection solar copra dryer was designed and constructed using evacuated tubes as the solar energy collecting source that can easily be assessed and maintained by local farmers for portable and household use. The construction was successfully carried out and the machine was tested under full load condition. The device has a thermal efficiency of $44.36 \%$ with average capacity of 20 $\mathrm{kg} / \mathrm{batch}$.

Results showed that, the temperature at $75{ }^{\circ} \mathrm{C}$ and blower velocity at $0.8 \mathrm{~m} . \mathrm{s}^{-1}$ with insulation thickness of $12.5 \mathrm{~mm}$ was found to be best combination for drying of copra. By using this combination the final moisture content was reduced to 6.47 per cent in $28 \mathrm{~h}$.

\section{References}

Ajisegiri, E. S. A., Alabadan, B. A., and Uche, I. K. (2006). Development of artificial dryer for yam chips. Nigerian Inst. Agric. Eng. 28: 348p.

Akpan, G. E., Onwe, D. N., Fakayode, O. A., and Offiong, U. D. (2016). Design and Development of an Agricultural and Bio-materials Cabinet Tray Dryer. Int. J. Food Eng. Technol. 2(1): 34-42.

Cornwel, K. (1978). The Flow of Heat Van Nostrand Reinhold Company Ltd. New York. 51p.

Geankoplis, C. J. (2011). Transport Processes and Separation Process Principles $\left(4^{\text {th }}\right.$ Ed.). PHI Learning Private Limited, New Delhi, 271p. 
Kulanthaisami, S., Subramanian, P., Mahendiran, R., Venkatachalam, P., and Sampathrajan, A. (2009). Drying Characteristics of Coconut in Solar Tunnel Dryer. Madras Agric. J. 96 (16): 265-269.

Mohanraj, M. and Chandrasekar, P. (2008). Comparison of drying characteristics and quality of copra obtained in a forced convection solar dried and sun drying. J. Sci. Ind. Res. 67: 381-385.

Sachidananda, S., Din, M., Chandrika, R., Sahoo, G.P., and Roy, S. D. (2014). Performance Evaluation of Biomass Fired Dryer for Copra Drying: A Comparison with Traditional Drying in Subtropical Climate. J. Food Process Technol. 5(1): 297p.
Shanmugam, V. and Natarajan, E. (2006). Experimental investigation of forced convection and desiccant integrated solar dryer. Renewable Energy 31: 1239-1251.

Sopian, K., Alghoul, M. A., Ebrahim, M., Alfegi, E. M., Sulaiman, and Musa, E. A. (2009). Evaluation of thermal efficiency of double-pass solar collector with porous-nonporous media. Renewable Energy 34: 640-645.

Tittarelli, F., Stazi, F., Politi, G., Perna, C. D., and Munafo, P. (2013). Degradation of glass mineral wool insulation after 25 years in masonry cavity wall. Inter. J. Chem. Environ. Biol. Sci. 1(5): 779783.

\section{How to cite this article:}

Sai Krishna V. and George Mathew. 2018. Development of a Solar Copra Dryer Incorporated with Evacuated Tubes. Int.J.Curr.Microbiol.App.Sci. 7(06): 2457-2465.

doi: https://doi.org/10.20546/ijcmas.2018.706.292 